\title{
FISCALIDAD EN NUEVA ESPAÑA. EL OBISPO Y EL CABILDO CATEDRAL DE MICHOACÁN ANTE LA CRISIS FISCAL BORBÓNICA*
}

\section{TAXATION SYSTEM IN NEW SPAIN. MICHOACAN'S BISHOP AND COUNCIL CATHEDRAL AT THE BOURBON FISCAL CRISIS}

\author{
Juvenal Jaramillo M. \\ Instituto Nacional de Antropología e Historia, Michoacán, México, \\ $<$ juvenal_jaramillo@inah.gob.mx>
}

\begin{abstract}
Resumen. En este artículo podemos ver el deterioro que comenzó a sufrir la economía eclesiástica michoacana 20 años antes del inicio de la guerra de Independencia. Aquí se llama la atención sobre mecanismos poco conocidos -por poco convencionalesutilizados por la corona española para obtener recursos económicos de las iglesias hispanoamericanas. Por medio de diversas cifras, en las cuales cada caso está contextualizado en el marco de la crisis fiscal española del tránsito de los siglos XVIII al XIX, podemos formarnos una idea de la cantidad de recursos que se trasladaron a la metrópoli en aquellos años, procedentes especialmente de la Iglesia de Michoacán y, eventualmente, de otras iglesias de Hispanoamérica.
\end{abstract}

Palabras clave: Iglesia católica; colonias; donativos; subsidios; anualidades, impuestos.

Abstract. This article sheds light on the deterioration that the ecclesiastical economy in Michoacan began to suffer some twenty years before the outbreak of Mexico's wars of Independence. This research draws attention to certain little known, indeed, somewhat unconventional, mechanisms that the Spanish Crown employed to extract economic resources from its churches in Spanish America. By analyzing diverse financial data that serve to contextualize each case within the framework of the Spanish fiscal crisis that spanned the late $18^{\text {th }}$ and early $19^{\text {th }}$ centuries, this essay allows us to form an idea of the amount of resources that were transferred to the metropolis in those years, principally from the Church in Michoacan but, more broadly, also from churches throughout Spanish America.

Key words: Catholic Church; colonial countries; donations; subsidies; annuities, taxes.

Fecha de recepción: agosto de 2012. Fecha de aceptación: noviembre de 2012.

* En la estructura y mejoramiento de este artículo colaboraron historiadores a quienes agradezco su tiempo y generosidad para leer y sugerir los cambios pertinentes. Ellos fueron quienes realizaron el dictamen para que fuese publicado en la revista América Latina en la Historia Económi$c a$, además de Brian Connaughton, Alfredo Ávila, Thomas Calvo y Carlos Herrejón.

Am. Lat. Hist. Econ., año 20, núm. 3, septiembre-diciembre, 2013, pp. 56-89 


\section{INTRODUCCIÓN}

$\mathrm{L}$ os envíos de donativos y préstamos de dinero por parte de las iglesias americanas a la península, para diversos fines, no fue un asunto exclusivo de finales del siglo XVIII y principios del XIX. Según hemos podido advertir, esa práctica provenía, por lo menos, de principios del siglo XVII. ${ }^{1}$ En lo primero que debemos llamar la atención aquí, pues, es en que las múltiples cantidades de dinero de que tratamos en este artículo y que se enviaron a la Real Hacienda se remitieron en un lapso extraordinariamente corto, a diferencia de lo que sucedió hasta antes de la década de 1790 y los años subsiguientes.

¿A qué obedeció lo anterior? Principalmente a que en las dos décadas que antecedieron al inicio de la guerra de Independencia en Nueva España la corona española instrumentó en un lapso muy corto diversas medidas tendentes a obtener más recursos urgentemente, agobiada en particular por las enormes cantidades de dinero impendido en las guerras internacionales sostenidas en esos años contra Francia e Inglaterra ${ }^{2}$ y por la multiplicación de salarios y pensiones. Una de aquellas medidas fue la aplicación de una mayor vigilancia acerca de los impuestos que debían pagar todos los súbditos de la corona; otra fue las cada vez más frecuentes solicitudes de donativos a particulares, corporaciones y especialmente a las iglesias novohispanas; una más fue el incremento de algunas cargas fiscales ya existentes y, una última fue la imposición de nuevas exacciones.

Las miras de los funcionarios de la Real Hacienda española se dirigieron en ese entonces particularmente hacia las iglesias que por entonces gozaban de una mejor salud fiscal, como lo eran los casos de México, Michoacán y Puebla. Por mencionar sólo un ejemplo, la declaración de guerra a Francia, en 1793, precisó al rey Carlos IV a que recurriese una vez más al clero de esas iglesias pidiéndole "sostener el honor de las armas españolas", proporcionando donativos de dinero. ${ }^{3}$

$\mathrm{Al}$ respecto, vale decir que ya hace varios años Herbert S. Klein observó que fueron precisamente las prolongadas y costosísimas guerras contra Francia (1793-1795) y contra Inglaterra (1796-1801 y 1805-1809) lo

\footnotetext{
${ }^{1}$ Véase una relación de diversos préstamos y donativos hechos a la corona por parte de la Iglesia de Michoacán en Archivo Capitular de Administración Diocesana Valladolid-Morelia (en adelante ACADVM), 6-6.4-145-103 y 104, años 1685-1891, fs. 25-29.

${ }^{2}$ Hemos considerado pertinente referirnos en este artículo a Inglaterra y no a Gran Bretaña por aparecer así en la documentación que hemos empleado para este trabajo.

Archivo del Cabildo Catedral de Morelia (en adelante ACCM), Libros de Actas de Cabildo, libro 38, años 1792-1794, Sesión de Cabildo, 25 de junio de 1793, fs. 115v.-116v.
} 
que colocó a la corona española en la urgente necesidad de echar mano de impuestos antes desdeñados, además de crear otros, incrementar otros más y, finalmente, recurrir a la petición de donativos y préstamos. ${ }^{4} \mathrm{~A}$ lo dicho anteriormente por Herbert S. Klein, debemos añadir -para redondear el panorama de los conflictos bélicos internacionales que hundieron fiscalmente a España- la ocupación que sufrió esta nación por parte de los ejércitos de Napoleón en 1808, lo cual precisó el envío de nuevos donativos y préstamos graciosos de sus posesiones.

Por ser la Iglesia la institución más poderosa económicamente en Nueva España, fue en ella en la que recayó el mayor peso de aquellas diferentes medidas dirigidas a la obtención de recursos. Sobre este punto cabe decir que ya algunos trabajos - principalmente de Carlos Marichal- han llamado la atención acerca de las contribuciones realizadas en aquellos años concretamente por las iglesias ${ }^{5}$ y por las diversas corporaciones eclesiásticas $^{6}$ para auxiliar a la corona ante la crisis suscitada por las guerras imperiales. Aún más, hace ya varios años David A. Brading tocó el tema para el caso de la Iglesia de Michoacán. ${ }^{7}$

Sin embargo, en los antedichos trabajos de Marichal y Brading -que son en los que se refiere concretamente el tema de los recursos económicos enviados por parte de la Iglesia a la corona principalmente para paliar los efectos de los conflictos bélicos- no han sido considerados algunos aspectos que nos hemos propuesto mostrar en el presente artículo. En primer lugar, aquí hemos pretendido ampliar el fenómeno de las remesas que en metálico enviaron algunas iglesias novohispanas a la Real Hacienda española entre 1790-1810, considerando para ello no solamente los préstamos y donativos (en que pone énfasis Marichal) o los nuevos impuestos (en que llama la atención Brading) sino también los recursos transferidos

${ }^{4}$ Klein, Finanzas, 1999, pp. 111-113.

${ }^{5}$ En Marichal (Bancarrota, 1999, pp. 140-161), podemos ver un panorama general de aquellos ramos fiscales que tenían como origen los diezmos, además de las bulas de Santa Cruzada, las vacantes mayores y menores, las medias anatas y las mesadas; todos ellos, ramos de donde Marichal sugiere que salía la mayor cantidad del dinero que era enviado a la península por parte de la Iglesia, ya por pertenecer al rey o ya en calidad de donativos y préstamos para enfrentar la crítica situación del momento.

${ }^{6}$ Aunque Marichal (Bancarrota, 1999), hace diversas referencias a la participación que tuvieron varias corporaciones eclesiásticas en el tema de los donativos y préstamos a la corona para atender sus urgencias económicas, en Valle (“Corporaciones", 1995, pp. 230-234, y "Apoyo", 1998, p. 140), podemos ver un interesante giro del asunto, al presentársenos al Consulado de Comerciantes de la ciudad de México como un "intermediario financiero" de diversas corporaciones eclesiásticas (como el Tribunal de la Inquisición, el Colegio de Indias de Nuestra Señora de Guadalupe, el Oratorio de San Felipe Neri, algunas cofradías, etc.), al remitir ciertas sumas de dinero a la corona en calidad de préstamo. Cabe aclarar, sin embargo, que en los antedichos textos la autora se refiere a un periodo más amplio que el que nosotros tocamos aquí.

${ }^{7}$ Brading, Iglesia, 1994, pp. 210-215. 
a la península por concepto de pensiones y limosnas -interesante variante de los donativos. Por lo demás, hemos considerado necesario traer a escena el factor del numeroso personal que giraba en torno al llamado antiguo régimen y de la nueva política reformista, como un elemento adicional al de las guerras y que significaba un constante y considerable gasto que buscó ser resuelto a través de dinero eclesiástico americano.

Además, se impone decir que por tratar este artículo sobre el caso del clero catedralicio michoacano, se han ampliado y profundizado algunos aspectos apuntados por Marichal y Brading sobre el tema, mostrando el desarrollo de diferentes casos que ilustran y ejemplifican algunos de los asuntos referidos por esos autores.

Por último, hemos considerado pertinente mostrar en este artículo cómo fue y en qué consistió la resistencia que presentaron los miembros del clero catedralicio michoacano a las diversas medidas tendentes a obtener fuertes cantidades de dinero en un corto tiempo.

\section{LOS DONATIVOS PARA LA GUERRA CONTRA LA FRANCIA REVOLUCIONARIA}

La respuesta dada por particulares e instituciones a los llamados de auxilio por parte de la corona española para sufragar los gastos de la guerra contra la Francia revolucionaria fue impresionante. Tan sólo el arzobispo de México, por sí y por el Juzgado de Capellanías, colaboró con la suma de 100000 pesos, mientras que el deán y Cabildo Catedral metropolitanos remitieron 60000 pesos, y el Juzgado General de Bienes de Difuntos de la capital novohispana hizo llegar a la Real Hacienda 320000 pesos. En ese tono de aportar gruesas cantidades de dinero para tal fin estuvieron el deán y Cabildo de Guadalajara, quienes aprontaron 300000 pesos; el senado episcopal poblano accedió a suplir fondos propios por un valor de 50000 pesos, y el Juzgado de Testamentos, Capellanías y Obras Pías de Valladolid de Michoacán aportó 40000 pesos. Por supuesto que también hubo corporaciones laicas y algunos particulares que desembolsaron elevadas cantidades para la guerra, como, por ejemplo, el Tribunal de Minería y el Consulado de Comerciantes de la ciudad de México, quienes aportaron 350000 pesos cada uno. ${ }^{8}$

${ }^{8}$ Archivo General de la Nación (en adelante AGN), Donativos y préstamos, vol. 1, exp. 80, fs. 317-318. Aquí podemos ver los nombres de particulares ricos como Francisco Ignacio Iraeta, el conde de la Cortina, Antonio Basoco, el marqués de Santa Cruz de Inguanzo, el marqués del Apartado, más otros muchos que entraron en las cooperaciones antedichas con considerables cantidades de dinero. 
No deja de ser interesante y no podemos dejar de llamar la atención sobre cómo la guerra contra la Francia revolucionaria, como ningún conflicto bélico anterior, generó en el obispado de Michoacán una respuesta casi "universal" en apoyo a la corona española, volcándose tanto en apoyos económicos como en actos litúrgicos a favor de esta última. ${ }^{9}$ Por lo que hace a los apoyos económicos del personal al servicio de la mitra, además del de algunos curas del obispado de Michoacán, nos encontramos con una larga lista en la que aparecen los nombres de algunos clérigos que años después ingresarían a las filas del Cabildo Catedral de Valladolid de Michoacán. ${ }^{10}$

Por su parte, en 1793 este mismo senado episcopal acordó que se contribuyese con 10000 pesos anuales mientras durase el conflicto bélico contra Francia, además de que decidió donar "los 30000 pesos que se prestaron a su majestad por el mes de enero de este año". Asimismo, dispuso que se contribuyese también con 3000 pesos anuales, mismos que se tomarían de los fondos de la fábrica material y del Hospital Real, de los cuales el rey era patrono.

A tales iniciativas de respaldo económico a la corona de España, para combatir a los revolucionarios franceses, se sumó también el obispo fray Antonio de San Miguel, quien decidió contribuir con 7000 pesos anuales. Inicialmente pues, la suma que enviarían tanto el obispo como los capitulares de la Iglesia de Michoacán sería de 20000 pesos anuales, pero esa cantidad se incrementó considerablemente una vez que el prelado fue informado de que la Iglesia de México estaba ofreciendo una cantidad mayor, por lo que envió un oficio a su Cabildo externándole que pensaba "que sería más decorosa y acaso más soportable la oferta de 65000 pesos,

${ }^{9}$ Por ejemplo, desde el mismo momento en que el obispo de Michoacán, fray Antonio de San Miguel, tomó conocimiento de los preparativos que se hacían en España para combatir a los franceses, envió a su cabildo un oficio para prevenirle de "las preces que se deben hacer en esta Santa Iglesia por el buen éxito de las armas españolas en la presente guerra contra Francia, y que se hagan las demás demostraciones que hubiere sido costumbre, avisándole de ellas para su personal concurrencia", por lo que el Cabildo Catedral decidió, inmediatamente, que al día siguiente se hiciesen en el coro "las preces que previene el ritual romano, y se toque rogación al mediodía y a la noche, e igualmente en las misas se eche la coleta propia del tiempo de guerra". Además, en la siguiente sesión de Cabildo se acordó que al día siguiente se realizara una procesión, "como en la octava de corpus", dándose repiques de campanas al entrar y salir de la iglesia, y que a la antedicha procesión se invitase a los prelados de las religiones y a estas, así como al intendente y al Ayuntamiento de la ciudad, cantándose misa solemne de rogación al concluir la procesión y haciéndose "una plática exhortatoria instruyendo al pueblo del fin por que se hacen estas deprecaciones". ACCM, Libros de Actas de Cabildo, libro 38, años 1792-1794, Sesiones de Cabildo, 25 y 26 de junio de 1793 , fs. 115v.-117.

${ }^{10}$ Tales eran los casos de Santiago Camiña, Francisco Antonio Cano de la Puerta, Miguel Díaz Rábago, Juan José Corral Farías, Gabriel Gómez de la Puente, Juan José de Michelena, Ramón de Pasos y Manuel Abad y Queipo. Véase Lemoine, Morelos, 1979, pp. 379-385. 
los 20000 a fin de este año y los 45000 en los tres años siguientes inmediatos, a razón de 15000 en cada uno". ${ }^{11}$

Por otra parte, es posible que más de alguno de aquellos prebendados haya pretendido cooperar en lo individual, con el propósito de figurar como buen patriota en las listas que enviaba el virrey a España, y utilizar tal elemento para engrosar sus méritos y servicios, sacando el correspondiente provecho en la menor oportunidad posible.

No menos digno de mencionarse es el hecho de que las autoridades virreinales solicitaron a todos los intendentes que les proporcionaran información sobre "las personas reputadas por un notorio caudal", seguramente para dirigirse a ellas y presionarlas a cooperar en los fines antedichos. ${ }^{12}$ Quizá por esto es que, una vez que el Cabildo Catedral tomó la resolución de cooperar como corporación, y no en lo individual, el prebendado Mariano Escandón -quien era el hombre más rico de la ciudad-envió, "por una sola vez, 10000 pesos para sufragar los gastos de la guerra contra los franceses". ${ }^{13}$

Es obvio que la afirmativa respuesta dada por las iglesias novohispanas a los llamados para combatir a la Convención tuvieron como telón de fondo la censura por parte del alto clero novohispano a la naturaleza y a la forma del movimiento revolucionario francés, y no sólo el espíritu patriótico. Sin embargo, es seguro que la prontitud e incondicionalidad con que se respondió a los antedichos pedidos, así como los montos de las cantidades enviadas, confirmaron en los altos círculos del gobierno el poderío económico de la Iglesia y su consecuente capacidad para soportar nuevos gravámenes, cosa que daría un argumento más para continuar en ese renglón.

Como era normal, sin embargo, los miembros de las iglesias, y en este caso concreto los de la de Michoacán, buscaron evitar una merma considerable a sus fondos, para lo cual se valieron de diversos argumentos, como veremos enseguida.

\section{LAS PENSIONES, LOS DONATIVOS Y LAS LIMOSNAS}

La etapa final de la guerra contra la Francia revolucionaria, en 1795, coincidió con la segregación del obispado de Michoacán de los extensos partidos de Colima, La Barca y Zapotlán el Grande, y su anexión al obispado de Guadalajara. ${ }^{14}$ Esta fue una de las medidas que más malestar y resen-

${ }^{11}$ ACCM, Libros de Actas de Cabildo, libro 38, años 1792-1794, Sesiones de Cabildo, 12 y 16 de julio de 1793 , fs. $120 \mathrm{v}$ - 121 y $123-124 \mathrm{v}$.

${ }^{12}$ AGN, Donativos y préstamos, vol. 1, exp. 50, f. 296.

${ }^{13}$ AGN, Archivo Histórico de Hacienda, leg. 1398, f. 162.

${ }^{14}$ Para un seguimiento detenido del proceso que concluyó con la segregación del obispado de Michoacán de esos partidos y su anexión al de Guadalajara, véase Jaramillo, Iglesia, 1996, pp. 111-154. 
timiento generó entre varios de los capitulares que vivieron de cerca el proceso de principio a fin, y de manera reiterada, sería uno de los velados reclamos del obispo fray Antonio de San Miguel y del Cabildo Catedral de Valladolid de Michoacán a las autoridades civiles metropolitanas.

Por ejemplo, cuando en abril de 1795 el virrey marqués de Branciforte envió a la Iglesia michoacana un oficio solicitándole un nuevo donativo para continuar la guerra contra Francia, la respuesta que se le dio fue inédita: que tanto el obispo como el Cabildo Catedral se encontraban imposibilitados para responder al nuevo pedido, pues las rentas de esta Iglesia habían tenido que sufrir "el grave demérito que le resulta de la segregación de los vastos partidos de La Barca, Zapotlán y Colima, que se han mandado agregar por su majestad a la de Guadalajara”, lo cual había reducido en una octava parte sus ingresos decimales. ${ }^{15}$

Además, decían aquellos clérigos, desde tiempo atrás el senado episcopal michoacano venía franqueando varias sumas para muy diferentes fines, amén de siempre concurrir con frecuentes y gruesos préstamos y donativos a la corona. Por ejemplo, en 1777 había contribuido con 80000 pesos para la construcción del astillero de navíos de guerra que se comenzó en el río Coatzacoalcos o Alvarado. Aparte, habían desembolsado una suma imprecisa pero muy elevada para las obras públicas que desde el año de 1786 se venían realizando en la ciudad de Valladolid de Michoacán para emplear a muchos vagos y mendigos. A todo eso, también había que agregar que cada año pagaban puntualmente "las pensiones que se le han impuesto para la orden carolina, patriarca de Indias, etcétera". ${ }^{16}$

¿Concretamente, a qué se referían el obispo y el Cabildo Catedral michoacanos con eso de las pensiones? A diferentes cantidades de dinero que desde el último tercio del siglo XVIII tenían que pagar las iglesias de la América española y las de Filipinas para muy diversos propósitos. Por ejemplo, tan sólo la Iglesia de Michoacán tenía que enviar a la metrópoli, cada año, una elevada suma de dinero para las siguientes personas e instituciones: para el capellán mayor del rey, 5000 pesos; para el príncipe de Sajonia, 3000 pesos; para don Juan Gálvez Escaño, 1000 pesos; para don José Muñoz de la Torre y don Felipe Martín Blanco, 666 pesos y cinco reales; para el Monte Pío Militar, 500 pesos; para el obispo de Luisiana, 800 pesos; para la Universidad de Salamanca, 2000 pesos; para el Colegio Seminario de Salamanca, 333 pesos y dos reales, y para la Real Orden de Carlos III, 4000 pesos, de los cuales el obispo aportaba 1500 y el Cabildo Catedral 2500 pesos. $^{17}$ En

${ }^{15}$ ACCM, Libros de Actas de Cabildo, libro 39, años 1794-1797, Sesión de Cabildo, 27 de mayo de 1795 , fs. $41-43$.

${ }^{16} \mathrm{Ibid}$.

${ }^{17}$ AGN, Justicia y Negocios Eclesiásticos, vol. 7, fs. 1-3. 
total, 17300 pesos al año, de unos ingresos por conceptos de diezmos que rondaban entre los 350000 y los 400000 pesos al año.

Hacia la década de 1790, pues, las "Iglesias de Indias" estaban cargadas con un elevado número de exacciones, así por el pago de diferentes impuestos como donativos, préstamos y pensiones. Con ellas se mantenían, parcial o totalmente, las órdenes de Carlos III $^{18}$ e Isabel La Católica, varias cátedras de la Universidad de Salamanca, el Colegio de Nobles de Madrid, la Biblioteca Real de Madrid, el cardenal patriarca de las Indias, el príncipe Clemente de Sajonia, los capellanes de Almadén, el Monte Pío Militar, ${ }^{19}$ el capellán mayor del rey y varios sujetos que vivían del statu quo del momento. ${ }^{20}$

De hecho, en ese escenario de crisis económica en la península y de racionalización administrativa, se decidió que los jueces hacedores ${ }^{21}$ de las

${ }^{18}$ Según Fonseca y Urrutia, esta orden se estableció por medio de una real cédula del 23 de abril de 1775 para recompensar los servicios de algunos personajes y sus hijos a favor de la corona. A partir de la creación de la orden española de Carlos III, se impuso la cantidad de 40000 pesos anuales de pensión "sobre las mitras y prebendas de las santas Iglesias de Indias", correspondiéndole al obispo y al Cabildo Catedral de Valladolid de Michoacán las cantidades que ya hemos referido. Véase Fonseca y Urrutia, Historia, 1850, p. 240. Sin embargo, Torales, teniendo frente a sí las Constituciones de la Real y Distinguida Orden Española de Carlos Tercero, ha señalado que la fecha de fundación de aquella orden fue el 19 de septiembre de 1771, y que la tal fundación se hizo por el rey Carlos III para reconocer y celebrar el nacimiento de su primogénito, el príncipe de Asturias, Carlos Clemente Antonio, el futuro Carlos IV. Ella sirvió, además, para condecorar a los ministros, prelados y miembros de la nobleza que se habían destacado por su lealtad al Estado; "a generales y almirantes e incluso a empresarios que destacaron por sus aportaciones al rey y mostraron su identificación con el monarca ilustrado tanto en la península ibérica como en los virreinatos y gobernaciones allende el Atlántico". Asimismo, esta autora indica que los nombramientos de miembros de la orden en cuestión le fueron reservados a la nobleza, "por lo que se exigió a los aspirantes a comprobar su limpieza e hidalguía". Véase Torales, "Imperial", 2009, pp. 353-354.

${ }^{19}$ De hecho, la pensión sobre el Monte Pío Militar se impuso por medio de una real cédula del 3 de junio de 1794, en la cual el rey Carlos IV señaló que, a partir de ese entonces y en lo sucesivo, las rentas decimales de las iglesias de México, Lima, Charcas, Santa Fe de Bogotá, Puebla de los Ángeles, Michoacán, Guadalajara, Cuzco, Arequipa y La Paz, quedarían gravadas con una pensión de 500 pesos anuales cada una, a favor del Monte Pío Militar. ACCM, Libros de Actas de Cabildo, libro 41, años 1802-1804, Sesión de Cabildo, 4 de mayo de 1804, f. 141-141v.

${ }^{20}$ Por ejemplo Juan Gálvez Escaño -quien había pintado el techo del anterreclinatorio de la Casa del Príncipe, en El Escorial, y era director de la Academia de San Fernando, en Madrid-; José Muñoz de la Torre, camarista del rey, y Felipe Martín Blanco, en la misma condición del anterior, por citar a algunos de aquellos. Vale decir que a la muerte de alguno de esos pensionados, algunos de sus parientes heredaban toda o una parte de la pensión. Por ejemplo, cuando en 1797 falleció Muñoz de la Torre, su pensión le comenzó a ser entregada a dos de sus sobrinos. ACCM, Libros de Actas de Cabildo, libro 42, años 1805-1806, Sesión de Cabildo, 11 de enero de 1806, f. 160-160v.

${ }^{21}$ No está de más recordar que en las catedrales más importantes de América había dos clérigos -generalmente dos miembros del Cabildo Catedral- que estaban encargados de todo lo referente a los diezmos, desde su recaudación hasta su distribución, pasando por la elección de los arrendatarios o administradores del mismo, según el caso. Uno de ellos era electo por el obispo -o por el vicario capitular, en caso de sede vacante- y el otro era electo por el Cabildo Catedral. 
catedrales fuesen ahora subcolectores de todas las pensiones antedichas (seguramente para ahorrar en el pago de más personal y aprovechar la eficiencia y adiestramiento en asuntos económicos de esos prebendados), y que esos clérigos se entenderían con los oficiales de las Cajas Reales de cada sede catedralicia, lo cual evidentemente llevó a una optimización e incremento en las recaudaciones, pues desde diciembre de 1800 hasta diciembre de 1802 se entregaron en la Real Hacienda 116000 pesos por parte de la Iglesia michoacana, tan sólo por lo correspondiente a la orden de Carlos III. ${ }^{22}$

Volviendo al asunto de los donativos, conviene decir que el contenido de alguna documentación nos deja ver que, en los casos de negativa a los apoyos solicitados por las autoridades civiles, venían represalias, lo cual nos lleva a concluir en que aquellos dineros sólo tenían de donativos el nombre, pues eran verdaderas cargas obligatorias disfrazadas de dádivas. Por lo que hace al temor a represalias ante la negativa de enviar los donativos, podemos ver el siguiente ejemplo: el deán Juan Antonio de Tapia, quien tenía una gran cercanía y amistad con el obispo fray Antonio de San Miguel, escuchó de boca de este que Branciforte había recibido muy mal la negativa de la Iglesia michoacana para una nueva cooperación que se le había pedido -también para solventar los gastos de la guerra contra Francia- "por cuyo motivo tal vez podría resultar una grave extorsión o acaso algún mal éxito en los negocios que tiene pendientes esta santa Iglesia", por lo que el Cabildo Catedral tomó prontamente el acuerdo de enviar un donativo de 10000 pesos, junto con una carta en la que le hablaban de los apuros económicos por los que atravesaba la Iglesia michoacana, y le puntualizaban que esa cantidad se había reunido luego de extraordinarios esfuerzos. ${ }^{23}$

Aquí tenemos pues que ahora los prebendados se encontraban en un callejón sin salida, pues si seguían pagando todos y cada uno de los impuestos y pensiones, y respondiendo a todas y cada una de las peticiones de donativos y préstamos ahora que ya no podrían contar con los diezmos de tres de los mejores partidos del obispado, tendrían que prescindir de los jugosos ingresos con que contaban antes de la década de 1790; pero la vía para evitar verse abrumados, la cual era negar a la corona donativos y préstamos graciosos, los preocupaba por la posibilidad de sufrir algunas represalias. De manera que, inmediatamente, el senado episcopal michoa-

\footnotetext{
A ellos es a los que se llamaba jueces hacedores, pues tenían facultades judiciales para castigar a los que defraudaban a la Iglesia con el pago del antedicho impuesto.

${ }^{22}$ ACCM, Libros de Actas de Cabildo, libro 41, años 1802-1804, Sesión de Cabildo, 11 de junio de 1803, fs. $72 \mathrm{v} .73$.

${ }^{23}$ ACCM, Libros de Actas de Cabildo, libro 39, años 1794-1797, Sesión de Cabildo, 12 de junio de 1795 , fs. $46-48 v$.
} 
cano acordó solicitarle al secretario del Cabildo y notario del Santo Oficio de la Inquisición, el bachiller Rafael de Crespo, que extendiese una certificación pormenorizando las cantidades y fines para los que la Iglesia michoacana había colaborado, tan sólo por donativos, desde el 15 de agosto de 1652 hasta el 17 de marzo de 1796, todo lo cual ascendía a la cantidad de poco más de 502000 pesos. $^{24}$

Es indudable que estamos ante una época en la que la crisis económica española fue trasladada a Nueva España, y que las fuertes sangrías económicas que aquellos reiterados donativos y préstamos graciosos, además del estrechamiento en la vigilancia de los pagos de impuestos y la aplicación de nuevas cargas al clero catedralicio, abrieron la zanja de la crisis económica en la Iglesia michoacana.

En este contexto, y precisamente en una nueva campaña de donativos, ahora para la guerra naval contra Inglaterra, ${ }^{25}$ se dio a conocer la real cédula del 25 de octubre de 1795 y el Nuevo Código, por medio de los cuales se reducía de manera muy considerable la inmunidad personal del clero americano. No fue, sin embargo, sino hasta casi cuatro años después, cuando el obispo fray Antonio de San Miguel le comunicó al deán Juan Antonio de Tapia que había

resuelto hacer representación a su majestad para que se sirva mantener al clero de América en la inmunidad personal que siempre ha gozado, y que habiendo de ir dicha representación acompañada de varios documentos auténticos, entre ellos el de los donativos, pensiones y limosnas con que se ha contribuido para todo género de obras por los prelados y Cabildo de esta santa Iglesia, pide se le pase certificación. $^{26}$

El argumento de los donativos, préstamos y limosnas se convertían, pues, en otro de los principales escudos con los que la Iglesia de Michoacán buscó detener los embates de la política borbónica contra sus privilegios, o al menos reducir su fuerza, y quizá en buena medida y por ello

24 "Certificación de donativos hechos por los ilustrísimos señores obispos y venerable Cabildo de esta diócesis para los efectos que se expresan, hasta la fecha que es a 17 de marzo de 1796", en ACADVM, 3-3.4-75-50, fs. 146-152v.

${ }^{25}$ Como ayuda a la corona española para esta nueva guerra, el clero catedralicio michoacano aprontó 50000 pesos que procedían de la parte del obispo en los diezmos, la parte del Cabildo Catedral en este mismo impuesto, y las partes que le correspondían a la fábrica material y al Hospital Real en ellos. ACCM, Libros de Actas de Cabildo, libro 40, años 1798-1801, pelícano del 2 de noviembre de 1798, f. 298v., y Sesiones de Cabildo, 6 de noviembre y 18 de septiembre de 1798, fs. $290-291$ y $375-375 v$.

${ }^{26}$ ACCM, Libros de Actas de Cabildo, libro 40, años 1798-1801, Sesión de Cabildo, 19 de noviembre de 1799 , fs. 389-389v. 
mismo sus respuestas a aquellos pedidos de auxilios fueron, hasta entonces, afirmativas.

Aquel argumento de los gruesos donativos y préstamos remitidos recientemente a la Real Hacienda, así como el velado reclamo por la desmembración de los partidos de Colima, La Barca y Zapotlán y por los nuevos impuestos fueron, pues, utilizados nuevamente en 1804 cuando el virrey José de Iturrigaray solicitó al Cabildo Catedral de Valladolid de Michoacán "una limosna anual" para el sostenimiento de los hospitales de San Antonio Abad y San Lázaro, petición a la que respondió el senado episcopal negativamente, pues no tenía dinero en ninguna de sus oficinas; y no tenía dinero, decía, por "los muchos reportes que está sufriendo la mesa capitular por razón de los donativos con que ha contribuido a su majestad, descuentos que se están haciendo por las medias anatas y tener que enterar lo correspondiente al subsidio nuevamente impuesto a todas la rentas eclesiásticas". ${ }^{27}$

Una vez más, cabe hacer hincapié en un concepto, el de limosnas, pues aunque obviamente no formaba parte del conjunto de exacciones que regular y cotidianamente tenía impuesta la Iglesia, aquellas constituían por lo general un apoyo económico para múltiples aspectos que estaban en el conjunto de los deberes del gobierno pero en los que tradicionalmente había colaborado siempre la Iglesia, como, por ejemplo, las obras públicas, el mantenimiento total o parcial de algunas instituciones piadosas, etc. Así pues, vemos que las limosnas eran solicitadas a la Iglesia por las autoridades virreinales, provinciales o locales para obras como el diverso tipo de construcciones o reconstrucciones, empedrado de calles, etc., o bien para hacer frente a una coyuntura como una epidemia o una crisis agrícola. Las limosnas estaban asociadas, pues, a la resolución de aspectos puramente sociales -a diferencia de los donativos y, naturalmente, de los impuestos y pensiones.

De cualquier manera, en los años a que nos estamos refiriendo y por el cúmulo de renglones por los cuales la corona consiguió dinero de la Iglesia, el proporcionar limosnas se había convertido en una carga casi imposible de atender para el clero catedralicio michoacano, por lo que en esos años se comenzaron a ver negativas como la ya referida.

${ }^{27}$ ACCM, Libros de Actas de Cabildo, libro 41, años 1802-1804, Sesión de Cabildo, 20 de enero de 1804, f. 113-113v. 


\section{LOS SUBSIDIOS ECLESIÁSTICOS DE 1795 Y 1799}

Este cambio de actitud de la Iglesia michoacana hacia los frecuentes pedidos de donativos y, ahora, de "limosnas", mucho tiene que ver también con lo ya dicho: el traslado de los partidos de Colima, La Barca y Zapotlán a Guadalajara, y las grandes sumas de dinero enviadas a la Real Hacienda para los fines ya antes mencionados y por las causas ya también referidas; pero en aquello también influyó, como decía el Cabildo Catedral en su respuesta a Iturrigaray, el "tener que enterar lo correspondiente al subsidio nuevamente impuesto a todas las rentas eclesiásticas".

¿A qué se referían los prebendados de la catedral michoacana con eso del "subsidio nuevamente impuesto"? En principio, hay que decir que, efectivamente, hablaban de una carga que de nuevo se les estaba imponiendo, porque los orígenes de los subsidios se remontan hasta la época del reinado de Carlos II (1665-1700). Sin embargo, al parecer no se puso atención en ellos sino hasta el 8 de marzo de 1721 cuando el papa Clemente XI concedió al rey padre, Felipe V, la facultad de cobrar 2000000 de ducados de plata, pero por una sola vez. Esa cantidad se prorratearía entre "todas las rentas de todo el Estado eclesiástico y regular de ambos sexos en los reinos de Indias y sus islas adyacentes", y su producto sería destinado a combatir a los musulmanes. ${ }^{28}$

El subsidio sería nuevamente aplicado en 1795 , merced a un breve dado en Roma el 7 de enero de ese año por el papa Pío VI, por medio del cual ese jerarca eclesiástico le concedió al rey Carlos IV la facultad de exigir de las rentas seculares y regulares de las iglesias de América y de Filipinas la cantidad de 30000000 de reales de vellón (1 500000 pesos fuertes), los cuales se habrían de entregar a la Real Hacienda en dos plazos y se destinarían a amortizar los vales reales recientemente expedidos en la península. ${ }^{29}$

En la prorrata que la Contaduría General de Indias hizo de aquella suma de 30000000 de reales de vellón, a pagar por las antedichas iglesias, a la de Michoacán le había correspondido la cantidad de 142246 pesos, misma suma que tuvo que presentar en las Cajas Reales en 1799, cuando otro breve papal -Grenoble, 7 de julio de 1799- concedía nuevamente a Carlos IV la facultad de pedir otro subsidio eclesiástico por la misma cantidad que el inmediato anterior. ${ }^{30}$ En suma, pues, fue la cantidad de 284492

${ }^{28}$ Según ACADVM, 3-3.4-75-50, f. 156, aquel subsidio de 1721 fue concedido por el papa Clemente XI debido a que no se verificó otro concedido por el mismo pontífice romano al mismo rey español por breve del 16 de enero de 1717.

${ }^{29}$ Archivo Histórico Casa de Morelos (en adelante AHCM), Diocesano, Gobierno, Mandatos, Aranceles, Bandos, Avisos, Borradores, caja 178, años 1800-1885, fs. s. n.

${ }^{30}$ Ibid. 
pesos la que desembolsó la Iglesia michoacana en sólo cuatro años, únicamente por concepto de "subsidio".

Además, el antedicho pago se hizo de manera puntual por la Iglesia michoacana, pues desde el 6 de marzo de 1790 el rey Carlos IV había expedido una real cédula en la que se enumeraba a todas las diócesis que, hasta la fecha, "habían incurrido en lastimosa lentitud y descuido" y no habían cumplido con remitir las cantidades de dinero de aquel subsidio de 1721; y en esa lista estaba la Iglesia de Michoacán, entre muchas otras, "de suerte que de las 42 diócesis que comprenden ambas Américas, únicamente las habían remitido los arzobispados de México, Manila y Guatemala, y los obispados de Nicaragua, Comayagua, Chiapa [...] y algunos pocos más". Con esto de "algunos pocos más" se refería a Cuba, La Habana y Oaxaca, pero para nada aparecía la diócesis michoacana. ${ }^{31}$

Desde el primero de aquellos subsidios, los subcomisarios de cruzada, medias anatas y mesadas eclesiásticas hicieron la recaudación en las sedes catedralicias, mientras que los curas párrocos lo hicieron en los límites de su parroquia. Esto obedeció, por un lado -posiblemente- al hecho de estar asociado ese dinero al mantenimiento de las tropas señaladas para combatir a los ingleses y para pertrechos de guerra (no olvidemos que lo recaudado por concepto de bulas de Santa Cruzada se utilizaba para combatir a los infieles), y posiblemente, también, por la mayor organización y celo en los asuntos hacendarios que muchos eclesiásticos mostraban, además de que contaban con la información precisa para aquel fin.

No podemos pasar por alto el mencionar lo que salta a la vista: que en este caso la corona española se valió de la propia infraestructura de recaudación fiscal de la Iglesia para llevar a cabo las colectaciones de los dineros, nuevamente con el doble propósito de aprovechar la eficiencia de aquellos clérigos en cuestiones fiscales y de ahorrar en burocracia.

Ahora bien, ¿qué ramos de la economía eclesiástica michoacana, así como fundaciones e instituciones, fueron gravados con esas cargas fiscales en 1795 y 1799? Según vemos, absolutamente todos, pues la circular por medio de la que se dio aviso al público hablaba de que aquellos dineros saldrían, desde "la masa decimal, réditos y proventos de esta Iglesia", hasta "las capellanías simples, archicofradías, rentas de conventos y hospitales religiosos, hospicios, casas de misericordia, todas las dotaciones piadosas", etcétera. $^{32}$

31 "Representación sobre subsidios de la lista y otros donativos", en ACADVM, 3-3.4-75-50, f. 163.

${ }^{32}$ He aquí la larga lista de ramos de la economía eclesiástica, instituciones y fundaciones que quedaron sujetas al pago de los subsidios eclesiásticos: "La masa decimal, réditos y proventos de esta Iglesia, exceptuando solamente los dos novenos de su majestad. Todo el producto libre de los curatos y doctrinas al cargo de clérigos seculares y regulares, incluso los sínodos que tuvieren de reales y las asignaciones fijas a sus vicarios que pasen de 30 pesos anuales; las sacristías mayores, 
Es decir, aquí estamos hablando nuevamente de un género de carga que, aunque sólo estaba en el ámbito de la Iglesia, tuvo amplios alcances, e incluso fue más allá, pues muchos laicos fieles se vieron también afectados al formar parte de cofradías, hermandades o archicofradías.

$\mathrm{Al}$ final de cuentas, pues, la Iglesia michoacana fue la tercera más gravada de las de América, con los antedichos 142246 pesos en cada subsidio, sólo por debajo de las iglesias de México y de Lima, que pagaron 175 446, la primera, y 149 328, la segunda, en cada una de las remesas en las que se dividió aquella nueva carga fiscal. En la prorrata formada para el pago de subsidios se advierte el orden de importancia económica que, en los últimos años del siglo XVIII, cada Iglesia ultramarina tenía para la Real Hacienda española; y así como todos los ramos e instituciones eclesiásticas de cada diócesis debieron participar con cierta cantidad de dinero, así todas las iglesias de la América española y Filipinas contribuyeron, sin excepción, según sus posibilidades y siguiendo aquel orden de importancia. De esta manera vemos que, inclusive, diócesis pobrísimas y que se sostenían con los diezmos que otros obispados les proporcionaban por la vía de pensiones y diezmos eclesiásticos -como Luisiana, Cebú y Nueva Cáceres- contribuyeron para los famosos subsidios (véase cuadro 1).

\section{LA ANUALIDAD ECLESIÁSTICA}

Evidentemente en esos años la corona española se encontraba en un callejón sin salida, pues a la vez que exprimía recursos de todos lados se veía cada vez más y más agobiada por los gastos de guerra y del elevado número del personal que las propias reformas borbónicas había generado. De manera que no bien pasaban los eclesiásticos aquel trago amargo de

\footnotetext{
las capellanías simples y las de castillos y fortalezas que excedan dicha cantidad de 30 pesos; todas las dotaciones piadosas destinadas para el culto de Dios y de los santos en todas las parroquias, iglesias y capillas seculares regulares, aunque pertenezcan a la orden de San Francisco o cualquiera de sus reformas, todos los frutos y proventos pertenecientes por cualquier título a la fábrica espiritual y a la colecturía de ánimas y aniversarios de esta santa Iglesia y las demás fábricas y colecturías de las parroquias de este obispado; todas las rentas de las archicofradías, cofradías, hermandades o congregaciones que gozan inmunidad real, esto es, que no pagan alcabala ni otros derechos reales en la venta de sus bienes ni de sus frutos; las rentas fijas de todos los conventos y hospitales religiosos y de todos los colegios de educación e instrucción de ambos sexos, ya consistan en fincas rústicas o urbanas o ya en censos, depósitos irregulares, enfiteusis, uso o usufructo o en pensiones sobre beneficios eclesiásticos o que les pertenezcan por cualquiera otro título: las rentas de los hospitales, hospicios y casas de misericordia que no estén en ejercicio actual de la hospitalidad, o que sin embargo de que la ejerzan tienen rentas sobrantes más de lo que necesitan para la asistencia de los pobres y enfermos." AHCM, Diocesano, Gobierno, Mandatos, Aranceles, Bandos, Avisos, Borradores, caja 178, años 1800-1885, fs. s. n.
} 
CUADRO 1. CONTRIBUCIONES DE LAS IGLESIAS

DE LA AMÉRICA ESPAÑOLA Y DE LAS ISLAS FILIPINAS

PARA LOS SUBSIDIOS ECLESIÁSTICOS, 1795 Y 1799

Diócesis
México
Lima
Valladolid de Michoacán
Puebla de los Ángeles
La Habana
Guatemala
Oaxaca
Guadalajara
Arequipa
Cuzco
Huamanga
Trujillo
Chile
Caracas
Durango
Santiago de Cuba
Charcas
Yucatán
Quito
Nicaragua
Santa Fe de Bogotá
Cartagena de Indias
Cuenca
Manila
Nuevo León
Chiapas
Santa Cruz de la Sierra
Tucumán
Comayagua
Concepción
La Paz
Guyana
Maracaibo
Nueva Segovia
Sonora

Cantidad a enviar

(en pesos)

175446

149328

142246

129880

84478

72232

70820

67000

55580

52420

39988

37426

31242

31020

30616

28392

26974

25612

22936

21500

20382

18692

17334

16608

15732

14030

10394

9978

9748

9354

8392

7506

7472

6486

5980 


$\begin{array}{lc}\begin{array}{l}\text { Diócesis } \\ \text { Popayán }\end{array} & \begin{array}{c}\text { (en pesos) } \\ \text { Panamá }\end{array} 620 \\ \text { Buenos Aires } & 5618 \\ \text { Paraguay } & 4794 \\ \text { Santa Marta } & 3882 \\ \text { Puerto Rico } & 2292 \\ \text { Nueva Cáceres } & 2246 \\ \text { Cebú } & 1052 \\ \text { Luisiana } & 824 \\ & 448\end{array}$

Fuente: AHCM, Diocesano, Gobierno, Mandatos, Breves, caja 179, años 1800-1897, fs. s. n.

los antedichos subsidios cuando sobrevino un nuevo impuesto: las anualidades eclesiásticas.

Las anualidades eclesiásticas fueron impuestas por real pragmática del 30 de agosto de 1800, y en ese documento se establecía que, además de los obispos, "las dignidades, canonjías y demás prebendas de presentación real de que se expiden títulos por la Cámara de Indias están sujetas al pago de la anualidad desde la publicación en Madrid de la pragmática" antes citada. $^{33}$

Nuevamente estamos ante un impuesto de grandes alcances dentro de la Iglesia. Se trataba de un impuesto consistente en un año de renta, y tenía que ser pagado, a partir de septiembre de 1800, por los obispos, por todos los prebendados de los cabildos catedralicios y por quienes gozasen de capellanías de 30 pesos para arriba, y de beneficios agregados -cualesquiera que fuese la posición de ellos. ${ }^{34}$

Vale decir que, al menos en el obispado de Michoacán, un muy alto porcentaje de los miembros del clero secular gozaba de alguna capellanía, ${ }^{35}$ así prebendados como curas párrocos, y aun varios sacerdotes sin destino alguno, lo cual nos permite nuevamente ver el carácter amplio de esa medida que afectaba no solamente al clero de mayores ingresos, sino hasta al más pobre.

${ }^{33}$ AHCM, Cabildo, Administración pecuniaria, Contaduría, Diezmos, caja 1544, años 18021819 , fs. s. n.

${ }^{34}$ Ibid.

${ }^{35}$ Según cifras proporcionadas por Brading (Iglesia, 1994, p. 250), hacia 1805 había en el obispado de Michoacán 1330 capellanías. 
Por lo demás, parece ser que la ya citada pragmática generó mucha confusión -además, seguramente, del natural descontento entre los contribuyentes-, por lo que el 21 de noviembre de 1804 don Manuel Sixto Espinosa envió al contador de rentas decimales de Guadalajara un breve expediente en el cual le pormenoriza quiénes, cómo y cuándo habrían de pagar. Ese documento fue reproducido en un número considerable y en él vemos que las dignidades debían pagar anualidad cada vez que pasasen de una silla a otra en una misma estalación, ${ }^{36}$ aunque no hubiese aumento de renta, pero sólo cuando se tratase de un movimiento o ascenso dentro de la misma iglesia. Además, siempre que hubiese alguno de aquellos ascensos de una estalación a otra, pero dentro de un mismo Cabildo Catedral, se debía cobrar la anualidad de toda la renta y no solamente de lo correspondiente al incremento de ella. Todo lo que mitigaba esta carga era que se podía pagar en cuatro partes y en el lapso de dos años. ${ }^{37}$

En una real cédula fechada en Madrid el 25 de julio 1806, vemos cómo deberían pagar la anualidad todos aquellos capitulares que fuesen trasladados de un senado episcopal a otro. Por supuesto, ahí se indica que el monto de la carga debería de ser el correspondiente a un año de renta, sólo que esos "agraciados" podían hacer el pago en el lapso de cuatro años. ${ }^{38}$

En la documentación que trata de las anualidades vemos que, en el obispado de Michoacán, el responsable de la recaudación fue el subcomisario de bulas y medias anatas, el canónigo Luis Zerpa Manrique de Lara, quien dio mucho de qué hablar, pues además de su característico excesivo rigor en las cuentas, actuó de manera irracional y arbitraria: mandó llamar a su oficina "a todos los contribuyentes de este obispado [...] para calificar sus exenciones y recursos. Hizo más: les señaló un término insuficiente, el cual era de 30 días para formar por menor las cuentas del último quinquenio de las rentas eventuales de curatos, sacristías, fábricas y comunidades religiosas y presentarlas en esta comisaría", además de que sujetó a la antedicha anualidad "muchas rentas notoriamente exentas de ella, como son las capellanías colativas, que no llegan a 30 pesos de renta; las capellanías laicales o patronato de legos, que no gozan inmunidad eclesiás-

\footnotetext{
${ }^{36}$ Se entiende por estalación cada una de las categorías en que se dividía la jerarquía capitular: dignidades, canónigos, racioneros y medios racioneros.

${ }^{37}$ AHCM, Cabildo, Administración pecuniaria, Contaduría, Diezmos, caja 1544, años 18021819 , fs. s. n.

38 "Sobre las cuotas que por razón de anualidad se han de pagar a la consolidación de vales reales en los respectivos casos de promoción, ascenso y primera entrada en las dignidades y prebendas de las Iglesias de Indias; se prescribe, asimismo, los términos en que han de satisfacerse", en ACADVM, 3-3.4-75-50, fs. 5-5v.
} 
tica; las limosnas por dispensas y los derechos judiciales de los juzgados eclesiásticos" ${ }^{39}$

Para limpiar su imagen de incumplido en algunos pagos, y a la vez protestar por tanto impuesto, petición de donativos y préstamos, pensiones y limosnas, es que a finales de 1804 el Cabildo Catedral de Valladolid de Michoacán tomó la resolución de dirigir una protesta a la corona. Fue esa una protesta en la que se enfatizaba un hecho: que la cada vez mayor pérdida de ingresos estaba llevando a una cada vez mayor pérdida de prestigio por parte de los prebendados de la catedral. No solamente había que tomar en cuenta que en los últimos 20 años se había presentado una galopante inflación, sino que ahora, con tanto incremento de impuestos y establecimiento de otros más, cuando un clérigo era favorecido con una pieza capitular tenía que pagar el equivalente al salario de 20 meses sólo por concepto de impuestos, entre mesada, media anata, anualidad, etc. En tales condiciones, pues, en ese momento ya se veía que los curas jueces eclesiásticos de los curatos pingües del obispado estaban mucho mejor remunerados que los prebendados de la catedral de menor jerarquía. La antedicha protesta terminaba con el siguiente colofón: "hemos rebajado mucho en estos últimos años en autoridad y en privilegios. Hemos rebajado también en renta proporcional a los demás vasallos por lo mucho que se nos ha gravado."

\section{EL NUEVO NOVENO REAL Y LA REAL CÉDULA DE CONSOLIDACIÓN}

El año de 1804 no podía terminar de peor forma para los interesados en la masa decimal, pero especialmente para los obispos y los miembros de los cabildos catedralicios -quienes eran los principales favorecidos durante la repartición de los diezmos-, pues 1804 terminó con la creación de un nuevo impuesto que gravaba los ingresos decimales: el llamado nuevo noveno real.

Hablar del nuevo noveno real es hablar, en estricto sentido, de una disposición de 1804 que, a diferencia de la real cédula de consolidación de vales reales, sí que afectaba directamente los ingresos económicos del clero catedralicio, pues, como es sabido, desde los orígenes de las iglesias novohispanas se practicó que, una vez reunido el monto de todos los diezmos, estos se dividían en dos mitades: una era para el obispo y el Cabildo Catedral -en porciones iguales-y la otra se dividía en nueve partes: cuatro eran para la parroquia de la misma iglesia catedral (que después se esta-

\footnotetext{
${ }^{39}$ ACCM, leg. 143, año 1804, fs. 153-156v.

${ }^{40}$ Brading, Iglesia, 1994, pp. 211-212.
} 
bleció que se aplicaran a los curatos pingües de la diócesis), tres para el Hospital Real y para la fábrica material de las iglesias -con un noveno y medio para cada uno- $y$, finalmente, dos novenas partes eran para el rey, ${ }^{41}$ los cuales eran los llamados dos novenos reales, que en estricto sentido era solamente un noveno, pues como ya se mencionó, ellos se derivaban de la mitad de los diezmos y no de la masa total de estos.

Pues bien, el 28 de noviembre de 1804, poco más de un mes antes de la expedición de la real cédula de consolidación de vales reales, se emitió un decreto real por medio del cual se mandaba que en todas las iglesias de Indias, una vez que se tuviese toda la masa de los diezmos y "antes de tocar en ella" para las divisiones acostumbradas, se sacase de ellos la novena parte y se depositase en las cajas de consolidación. Los argumentos para tal determinación fueron, una vez más, decía el rey Carlos IV, "los crecidos gastos que ha hecho inexcusables la defensa de mis dominios de España e Indias para preservarlos de los estragos de la guerra y otros males", además de atender las calamidades públicas con las que habían comenzado varias ciudades españolas el siglo XIX. Para tal medida, el antedicho monarca contaba con la concesión del papa Pío VII, quien por medio de un breve dado en Roma el 3 de octubre de 1800 había dado luz verde a la nueva exacción real. ${ }^{42}$

Está de más decir que el nuevo impuesto significaba reducir en 11\% los ingresos de todos los interesados en los diezmos, los cuales eran, principalmente y según hemos ya dicho, los obispos y los miembros de los cabildos catedrales. Sin embargo, no hubo una resistencia a esa nueva carga fiscal, sino a la forma en que se pretendía realizar, pues las urgencias del rey eran tales que exigía aquel dinero inmediatamente, lo que provocó que en seguida viniese toda una cascada de representaciones a la corona, en las que le explicaban al rey por qué no era posible atender con esa prisa sus exigencias. Todas las iglesias novohispanas formaron representación, menos la de Yucatán, y al parecer aquella andanada de representaciones fue encabezada por el Cabildo Catedral de Valladolid de Michoacán, según se ve en el expediente que trata este caso. La mayoría de esas representaciones seguían el mismo tono de la de Michoacán y coincidían en que no se podían deducir los novenos reales inmediatamente, es decir, no se podían sacar los novenos de 1804 en ese mismo año, ni los de 1805 en ese año, ni los de 1806 para entonces, etc. Había que esperar, por lo menos, dos años, como había sido la costumbre y práctica desde los primeros tiempos, pues sólo después de ese periodo y luego de haber colectado los productos en todos y cada uno de los diezmatorios, haber vendido lo que había que

\footnotetext{
41 "Testimonio", 1998, pp. LXI-LXII.

${ }^{42}$ AGN, Diezmos, vol. 21, fs. 219-221, y ACADVM, 3-3.4-75-50, f. 119.
} 
vender, haber cotejado lo recaudado en el año actual con el anterior, etc., se podía contar con la masa general del diezmo. Sacar el nuevo noveno inmediatamente, es decir en 1804, equivalía a gravar los diezmos de 1802 y 1803 -por lo menos-, cosa que era contraria a los intereses de los partícipes de los diezmos y a toda justicia y lógica. ${ }^{43}$

No debería contarse en la Real Hacienda con el nuevo noveno sino hasta 1807.

Ya para entonces habremos acabado de pagar el subsidio que nos rebaja una novena parte de nuestra renta, habremos también acabado de pagar los 25000 pesos de donativo que ofrecimos en este año ${ }^{44}[\ldots]$ y de esta suerte sucederá en su lugar la deducción del noveno y quedaremos en el mismo estado en que nos hallamos; pero si al subsidio y al donativo que estamos satisfaciendo se agregara la rebaja de una novena parte de nuestra renta inseparable de la deducción del noveno, vendríamos a carecer de la cuarta parte de renta que hasta el día hemos tenido, y las otras tres cuartas partes quedarían sujetas a la anualidad y media anata, lo cual no puede verificarse justamente o a un tiempo mismo sin dejar muy incongruos a los muchos señores que tienen aún pendiente la paga de la media anata y anualidad

decían los jueces hacedores de la catedral michoacana en 1805, quienes fueron comisionados por sus colegas capitulares para formar la antedicha representación de la Iglesia michoacana. ${ }^{45}$

Aquella explicación de los jueces hacedores de la catedral michoacana obligó a los fiscales de la Real Hacienda a consultar con todos los contadores reales de diezmos de Nueva España sobre si era cierto que los diezmos se repartían hasta, por lo menos, dos años después de su recaudación, lo cual fue contestado afirmativamente por todos ellos. Inclusive algunos, como el contador real de diezmos de Puebla y el contador real de diezmos de Monterrey, señalaron que en esas diócesis la repartición se hacía con tres años de retraso. ${ }^{46}$

Las razones y los argumentos dados por parte de la Iglesia michoacana fueron finalmente atendidos, y se concluyó en que fuese hasta que se devengasen los diezmos de 1805 cuando se dedujese el nuevo noveno real, para evitar dejar en la incongrua a los obispos y a los prebendados de las catedrales. ${ }^{47}$

${ }^{43}$ AGN, Diezmos, vol. 21, fs. 274-280.

${ }^{44}$ Se refiere al donativo que, en Sesión de Cabildo, 2 de mayo de 1805, el Cabildo Catedral de Valladolid de Michoacán acordó dar en apoyo a la corona española para sufragar los gastos de la guerra contra Inglaterra. Véase ACCM, Libros de Actas de Cabildo, libro 42, años 1805-1806, Sesión de Cabildo, 2 de mayo de 1805 , f. 44-44v.

${ }^{45}$ AGN, Diezmos, vol. 21, fs. 274-280.

${ }^{46}$ Ibid.

${ }^{47}$ Ibid. 
Sin embargo, lo verdaderamente interesante de todo este asunto es un extenso informe que realizaron los jueces hacedores de Michoacán, y que fue presentado el 26 de agosto de 1805 a sus colegas capitulares. En aquel se ven las críticas condiciones en que comenzaban a quedar los prebendados a raíz de los muchos donativos y préstamos concedidos a la corona y de la imposición de las cargas fiscales ya mencionadas a lo largo de este artículo: un provisto a medio racionero tenía que pagar por media anata y anualidad 2478 pesos, mientras sus ingresos durante los dos primeros años eran de 1800 pesos, "con lo cual resulta que en los seis primeros años de su prebenda no puede contar más que con la mezquina mesada de 75 pesos para todas sus necesidades, para su decente sustentación”. Y en el "feliz caso" de que ese medio racionero fuese promovido a una ración, tendría que volver a pagar, pero ahora más: "por razón de media anata y anualidad adeudará 4950 pesos", lo cual volvía a repetir el círculo, de manera que si ese racionero moría al quinto año de su toma de posesión, "morirá tan quebrado como un medio racionero, y esto después de haber servido diez años en una de las iglesias más principales del reino y que se considera una de las más opulentas". ${ }^{48}$

Es difícil establecer hasta dónde todo lo anterior era pura demagogia o una razón puntual sobre los inicios de la decadencia del poder económico del clero catedralicio, pero hay que agregar que en el antedicho informe, además, se expone la concepción que tenían sus autores (si no es que la mayoría de los prebendados) sobre una prebenda, esta era el premio a muchos años de trabajo sacerdotal, muchas veces hasta 30 años de labor. ¿Pero qué pasaba ahora con la nueva política fiscal borbónica? Pasaba que el querer llegar a una media ración, y no se diga hasta una canonjía o a una dignidad, era desde el punto de vista económico cada vez menos atractivo y posible para muchos sacerdotes, ya que "tanto entre los señores racioneros como entre los medio racioneros tenemos muchos ancianos porque entran en sus prebendas después de 30 y aun 40 años de curas, que han venido a recibir por premio único y total de su dilatado y penoso ministerio una escasa mesada para acabar sus días acaso llenos de drogas y amargura”. Había pues que escuchar lo expuesto por los prelados de las órdenes religiosas y por muchos vecinos importantes de la ciudad de Valladolid de Michoacán, en el sentido de que un prebendado, "para su precisa moderada correspondiente manutención necesita a lo menos 4000 pesos anuales", no aquellos 1800 que percibían en ese entonces, y de que hablamos antes. ${ }^{49}$

\footnotetext{
${ }^{48}$ ACCM, Libros de Actas de Cabildo, libro 42, años 1805-1806, Sesión de Cabildo, 2 de septiembre de 1805, fs. 93-103.

${ }^{49}$ Ibid.
} 
Punto no menos interesante en aquel informe de los señores jueces hacedores de Michoacán es que se pone en tela de juicio toda la política fiscal borbónica cuando se enfatiza el hecho de que cuando el papa Alejandro VI donó los diezmos a la corona española lo hizo precisamente a condición de que la congrua de los ministros de la Iglesia fuese suficiente, pero "en el nuevo sistema queda incongrua la mayor parte del Cabildo", sentenciaban. ${ }^{50}$

Por lo demás, la fábrica espiritual también quedaría incongrua, pues con el nuevo noveno se le quitarían 3709 pesos y cuatro reales; con el subsidio eclesiástico 1881 pesos y cuatro reales, y con el más reciente donativo de 25000 pesos, para sufragar la guerra contra Inglaterra, 1100 pesos. En resumen, pues, los tiempos de crisis de la monarquía española traían sólo perjuicios a las iglesias novohispanas y pocos beneficios a la Real Hacienda española, lo cual tendría su traducción final en un asunto social sumamente delicado; al quedar estrechísimos en sus rentas, los capitulares no podrían socorrer ni a los muchos pobres vergonzantes ni a los demasiados mendigos que había en la ciudad, "porción de vasallos la más digna de la compasión y protección del rey nuestro señor y de su corona”. El ya citado informe se cerraba con un lamento-sugerencia: "iCuánto mejor y más útil sería dejar la gruesa decimal exenta de todo gravamen, en el estado antiguo, imponiendo sobre ella un 5\% a beneficio de las necesidades de la corona!"51

El asunto era extraordinariamente espinoso, por lo que para asumir una posición muy templada y concienzuda ante la corona se decidió que el informe en cuestión fuese examinado por una junta integrada por los jueces hacedores autores de aquel, los doctores Ramón Pérez Anastariz y Manuel de la Bárcena, por el canónigo doctoral Gabriel Bartolomé Gómez de la Puente y por el juez de testamentos don Manuel Abad y Queipo, quienes presentaron al Cabildo Catedral sus conclusiones sobre las varias cargas fiscales que en los últimos años habían tocado la economía eclesiástica. En principio, sugerían que el Cabildo Catedral no se manifestase más como corporación respecto de la anualidad eclesiástica, sino que en lo particular, cuando alguno de sus individuos fuese promovido y se le requiriese la anualidad de toda su nueva renta, expusiese "las razones y robustos fundamentos que hay para que sólo se les exija del aumento y no del todo de la renta de la prebenda a que ha ascendido, para que el colector pueda dar cuenta apoyando esta justa solicitud a la Junta de Consolidación”. Es decir, una nueva táctica dilatoria para atrasar el pago de la anualidad y para, entre tanto, dar tiempo a que el juez de testamentos, Manuel Abad y

${ }^{50}$ Ibid. 
Queipo, "vaya trabajando el informe que deberá ir a nombre del venerable Cabildo sobre anualidad, contrayéndolo al aumento y no al todo de la renta para mejor robustecerlo". ${ }^{2}$

A riesgo de resultar reiterativos, hemos de insistir en que, a diferencia de la real cédula de consolidación de vales, aquel decreto real sobre el nuevo noveno sí impactaba directa y considerablemente en los ingresos del clero catedralicio y, por lo tanto, ponía a los miembros del clero catedralicio michoacano en dificultades para nuevos apoyos económicos a la corona. Sin embargo, el Cabildo Catedral de Valladolid de Michoacán, que desde julio de 1804 se encontraba en sede vacante por muerte del obispo fray Antonio de San Miguel, decidió también expresar su desacuerdo con la famosa cédula de consolidación de vales, por medio de una representación fechada el 3 de octubre de 1805.

Según se puede ver en la antedicha representación, el Cabildo Catedral de Valladolid de Michoacán no manifestó en ella su preocupación por los posibles efectos que la aplicación de la cédula en cuestión pudieran tener en la economía catedralicia, sino por el enorme daño que ocasionaría a miles de particulares la puesta en vigor de los artículos 15 y 35 del reglamento para la enajenación de bienes raíces de capellanías y obras pías, en los que se mandaba a los deudores de aquellos ramos que entregasen de contado alguna cantidad de los principales, el resto entrase en composición acordando con la correspondiente junta subalterna el plazo para redimir la cantidad restante, y finalmente el traslado de sus capitales a la caja de consolidación. ${ }^{53}$

Concretamente, pues, los primeros, principales y directos afectados en la diócesis de Michoacán con la aplicación de la real cédula de consolidación no sería el Cabildo Catedral sino poco más de 2300 personas de ambos sexos, entre quienes se encontraban distribuidos a manera de préstamos hipotecarios aquellos fondos de capellanías y obras pías que pedía la corona que se le enviasen. Pero lo grave del asunto estribaba en que entre aquellas personas se encontraban muchos agricultores, mineros y comerciantes que sin los referidos fondos se verían imposibilitados para sostener esos giros, además de que entre ese número de deudores se encontraban muchos pobres con cortas deudas sobre fincas urbanas, y entre ellas se contaban "muchas mujeres viudas, viejas, huérfanas y personas miserables". ${ }^{54}$

${ }^{52}$ ACCM, Libros de Actas de Cabildo, libro 42, años 1805-1806, Sesión de Cabildo, 7 de octubre de 1805 , f. 119.

${ }_{53}$ "Representación", en Sugawara, Deuda, 1976, p. 48.

${ }^{54}$ Ibid. 
Algo que no dijeron los prebendados de la catedral michoacana en esa representación es que, entre aquellos 2300 probables afectados por la puesta en vigor de la real cédula de consolidación, se encontraban varios miembros del Cabildo Catedral de Valladolid de Michoacán como propietarios o familiares de propietarios de fincas rústicas y/o urbanas que eran afectas a capitales de capellanías y obras pías.$^{55}$ Es decir, pues, además de su posible preocupación por los inevitables efectos negativos que tendría la aplicación de la cédula de consolidación en el conjunto de la economía novohispana, en aquellas palabras de los capitulares subyace preocupación por la afectación directa a los intereses particulares de algunos de ellos.

Finalmente, no sabemos si los prebendados-propietarios que tenían deudas con el juzgado de testamentos, capellanías y obras pías fueron afectados con la puesta en vigor de la real cédula de consolidación de vales reales, pero la inexistencia de datos al respecto insinúan que aquellos lograron salir bien librados del asunto, quizá consiguiendo alguna composición o el atraso del proceso por lo que hace a su asunto, hasta los días en que se canceló la antedicha real cédula.

\section{EL DONATIVO Y EL PRÉSTAMO DE 1805 \\ PARA LA GUERRA CONTRA INGLATERRA}

Por el espectro de la cédula de consolidación, hacia 1805 el escenario en Nueva España era desolador. Pero aún las cosas estaban muy lejos de mejorar para los miembros del alto clero novohispano, pues si bien no se crearon ya nuevos impuestos ni se incrementaron los ya existentes, y se estaba a la espera de las respuestas a las múltiples representaciones y con la esperanza puesta en una marcha atrás de la puesta en vigor de la real cédula de consolidación, una nueva guerra contra Inglaterra precisó a la

\footnotetext{
${ }^{55}$ Algunos de los capitulares-propietarios figuran como firmantes de la representación que el 24 de octubre de 1805 redactó el juez de testamentos, capellanías y obras pías de la catedral de Valladolid de Michoacán, Manuel Abad y Queipo, a nombre de los labradores y comerciantes de la capital michoacana. Entre ellos podemos ver a José Flores Estrada, Eduardo Espinoza de los Monteros y Plata, José Ignacio Álvarez Gato, Manuel García Cubilano y Miguel Díaz Rábago. Llama la atención que todos ellos ocupaban piezas capitulares de baja jerarquía y, por lo tanto, de ingresos reducidos. Quizá esta situación fue la que los llevó a asumir una postura más activa frente a la disposición real en cuestión. También vemos en aquella lista nombres como el del secretario de la cámara del obispo y hombre muy cercano al Cabildo Catedral, don Santiago Camiña; el del juez de testamentos, capellanías y obras pías y también muy vinculado al senado episcopal, Manuel Abad y Queipo, y los de varios curas y familiares de prebendados. Sugawara, Deuda, 1976, pp. 70-75.
} 
corona española a solicitar nuevos préstamos y donativos a las iglesias americanas a fin de fortificar los situados del Caribe.

En 1804, a decir de Miguel Cayetano Soler, ministro de Hacienda de Carlos IV, Inglaterra había violado la paz cuando una división de buques de guerra con bandera británica, a las órdenes del almirante Nelson, habían apresado cuatro fragatas de la Real Armada española que se dirigían de Montevideo a España con caudales, y habían cometido contra ellas, en el Mediterráneo, "hostilidades de un modo no sólo escandaloso, sino inaudito". ${ }^{56}$

Además del inevitable inicio de la guerra, otros factores totalmente fuera de control preocupaban a las autoridades españolas: por principio de cuentas, la hambruna que se experimentaba en la mayoría de las poblaciones de la península "por la falta total de las dos últimas cosechas" que se habían perdido por la sequía y habían generado una inflación sin precedentes; además, en la península se había hecho presente una peste que afligía las ciudades y puertos de Cartagena, Alicante, Cádiz y Málaga, las cuales estaban en cuarentena y cerradas por mar y tierra. Asimismo, al resto de las provincias de Castilla las azotaba una epidemia de tercianas, mientras que varios terremotos habían destruido un considerable número de pueblos de la costa de Andalucía. Por si todo eso fuera poco, desde su derrota con la Francia revolucionaria la corona española estaba obligada a pagarle a esa nación 60000000 de reales al año por concepto de un "subsidio de neutralidad" que, reconocía el ministro de Hacienda, había “absorbido enteramente los caudales" que se habían remitido desde Nueva España. ${ }^{57}$

De manera pues que, según decía el virrey Iturrigaray al senado episcopal michoacano en un oficio fechado el 19 de febrero de 1805, el rey Carlos IV le había ampliado sus facultades para que buscase los arbitrios que considerase más prudentes para allegarle fondos al Real Erario; y “después de muy detenida reflexión”, Iturrigaray no encontró otro recurso "más fácil, pronto, sencillo y exento de perjuicio" que el que las iglesias novohispanas le hiciesen llegar, en calidad de préstamo, todos los fondos existentes en la fábrica material. ${ }^{58}$

56 "Valladolid, año de 1805. Testimonio sobre donativo de la cantidad de 25000 pesos pagadera por tercios en diciembre de 805, 806 y 807, ofrecido por el muy ilustre venerable señor deán y Cabildo de esta santa Iglesia para las actuales urgencias de la corona”, en ACCM, leg. 144, año 1805, f. 32.

${ }_{57}$ Ibid.

58 "Valladolid, año de 1805. Testimonio del expediente formado en consecuencia del oficio del excelentísimo señor virrey a fin de que para las actuales urgencias del Real Erario se franqueen a su majestad en calidad de préstamo las existencias del fondo de fábrica de las iglesias catedrales, y para que los gastos extraordinarios, como reparos mayores de la fábrica material, provisión de paramentos, alhajas y otros semejantes no se hagan sin noticia y anuencia del vicepromotor real 
Es seguro que ni el virrey Iturrigaray ni sus ministros tomaron en cuenta que una de las razones de ser de los cabildos catedrales era, precisamente, cuidar y promover el esplendor del culto, lo cual estaba muy íntimamente en relación con los dineros existentes en el ramo de fábrica material de las iglesias, y del que echaban mano para tal fin. En síntesis, sin dinero en la fábrica material no habría tal esplendor del culto, y sin esto el papel de los cabildos catedrales quedaba reducido, violando con ello los prebendados el juramento prestado al momento de tomar posesión. Pero eso no era todo, además, Iturrigaray encargaba al senado episcopal michoacano que a partir de ese momento no fuesen a hacerse gastos muy fuertes en reparaciones del edificio catedralicio, ni en "provisión de ornamentos, alhajas y otros semejantes", sin primero darle noticia a él y sin contar con su anuencia, "suspendiéndose desde luego cualesquiera de las obras e inversiones de dicha clase que se hayan emprendido sin aquel requisito"..$^{59}$

Como salta a la vista, tal medida del virrey Iturrigaray debe ser tomada como una extralimitación de sus facultades como vicepatrono real -a pesar de que el rey Carlos IV le había ampliado sus facultades-, pues con ello se intentaba arrebatarle a los cabildos catedrales y a los obispos la facultad de administrar los caudales de fábrica y emplearlos discrecionalmente en las cosas pertenecientes al culto divino, una facultad que les venía desde los inicios mismos de las iglesias en Nueva España.

El asunto era pues de seriedad, y vemos que ya la crisis económica española llegaba hasta las entrañas de la Iglesia y repercutía en una arrogación de facultades por parte de la autoridad civil, por lo que la respuesta del Cabildo Catedral de Valladolid de Michoacán fue, de momento, que se tomarían un tiempo para que todos y cada uno de los prebendados meditaran con la atención correspondiente y pudieran resolver sobre el asunto, pero sin descuidar una ni otra cosa: las responsabilidades de dotar suficientemente la fábrica material, a la vez que proporcionar auxilios a la corona. Sin embargo, adelantaban al virrey "que en el corazón de cada uno de nosotros están vivamente impresos los más tiernos sentimientos de dolor por las presentes urgencias de la corona, y que para sufragio estamos prontos a apurar todos nuestros arbitrios hasta el sacrificio de nuestra propia sangre". ${ }^{60}$

De la estructura del expediente en el cual se trata este tema deducimos que, además de dar tiempo a todos y cada uno de los capitulares para

y que se suspendan desde luego las inversiones de esta clase que se hayan emprendido sin aquel requisito", en ACCM, leg. 144, año 1805, f. 42v.

${ }^{59}$ Ibid., fs. $42 \mathrm{v} .-43$.

${ }^{60}$ Ibid. 
que meditaran serena y macizamente sobre el negocio en turno, el senado episcopal michoacano estaba dando tiempo para esperar la respuesta que el Cabildo Catedral Metropolitano daría a semejante determinación del virrey Iturrigaray, y con ello normar su criterio. Y así fue, según podemos cotejar en una y otra respuesta, las cuales marchan sobre idénticos ejes. La réplica fue que, de cumplir con aquella disposición, quedarían desatendidas las necesidades de la Iglesia, pues en la actualidad carecían de ornamentos decentes para celebrar las misas, "no habiendo apreciables sino algunos pocos destinados de las funciones clásicas, que por lo mismo están exentos del servicio cotidiano". Por lo demás, "sus retablos, que son muy antiguos, presentan un aspecto negro e indecoroso que está pidiendo, por lo menos, alguna reforma". Respecto al sagrario de la catedral michoacana, no había un espacio que fuese digno de ese nombre, "porque apenas pudo darse en años pasados alguna más cavidad a una de sus pocas capillas que todavía es insuficiente y no proporciona todo el ámbito que es preciso para el concurso de los fieles en la recepción de los santos sacramentos". Pero el punto principal era el templo, demasiado estrecho para dar cabida "no ya al numeroso pueblo de esta ciudad, mas ni aun al ilustre Ayuntamiento, comunidad de religiosas, clero, colegios y sujetos de distinción que asisten a las festividades solemnes". Con todo y esto, decían los prebendados michoacanos, si las urgencias del Real Erario eran tales que estaba en riesgo el Estado, ellos estaban dispuestos a sacrificar no sólo los caudales de fábrica material, "sino también su propia renta y aun los vasos sagrados, reservando únicamente lo que es indispensable para tributar a Dios el culto debido". ${ }^{61}$

Además de la anterior respuesta, el Cabildo Catedral de Valladolid de Michoacán decidió encargarle al abogado doctoral, Francisco de la Concha Castañeda, que preparase una muy sólida y nerviosa representación. Y así fue, Concha redactó una representación en la que citó las disposiciones del Concilio de Trento en la materia, lo que decía Solórzano y Pereira en De Gubernatione Indiarum, lo puntualizado en la Recopilación de Leyes de Indias y lo dicho en muchas reales cédulas y otros diversos papeles al respecto. En síntesis, que los fondos de fábrica eran de dominio y uso de los obispos y cabildos catedrales para sostener el culto divino. Además, a la antedicha representación se anexó un informe de los claveros Gabriel Bartolomé Gómez de la Puente y Francisco de Borja Romero Santa María, en el cual afirmaban que era de la fábrica de donde se daban las libranzas por adelantado a los prebendados en tanto se hacían los repartimientos de diezmos. ${ }^{62}$

\footnotetext{
${ }^{61} \mathrm{Ibid}$.

${ }^{62}$ Ibid., fs. $48 \mathrm{v} .-50 \mathrm{v}$.
} 
De manera terminante, aquella representación se concluyó con la oferta de enviar al virrey la cantidad de 50000 pesos en calidad de préstamo, pero a cambio de que "con atención a todo se sirva su excelencia sobreseer en la inhibición" que contenía su oficio, y de que ya hemos dado cuenta, y con la advertencia de que, de no llegar a un acuerdo, dirigirían otra representación al rey, y para ello ya tenían instruido al especialista en la materia, Manuel Abad y Queipo, además del canónigo doctoral, Gabriel Bartolomé Gómez de la Puente. ${ }^{63}$

Dada la gravedad de la situación, el virrey José de Iturrigaray decidió cambiar de táctica y aceptar aquellos 50000 pesos por vía de préstamo, retirar su intento de intromisión en la fábrica y, ahora, pedir un donativo, para lo cual nuevamente envió un oficio al Cabildo Catedral de Valladolid de Michoacán, fechado el 31 de marzo de 1805, y en cual se apelaba a "la acendrada fidelidad de los cuerpos y vasallos de este reino, y al celo y rectitud constantes de vuestra excelencia, de los prelados y cuerpos eclesiásticos y civiles y de los jefes subalternos de las provincias". ${ }^{64}$

No sabemos si fueron esas palabras o la dolorosa pintura que desde un principio se les había mostrado a las autoridades virreinales sobre lo que vivía España, y de las que ya dimos cuenta líneas antes, pero el caso es que el Cabildo Catedral de Valladolid de Michoacán señaló que la lectura de semejantes cosas había sido "capaz de excitar la indolencia del corazón más indiferente", y que en el ánimo de todos los señores capitulares había hecho "la más viva impresión", por lo que estaban dispuestos a hacer un nuevo esfuerzo, aunque en la catedral michoacana ya no habían otros fondos que los de la fábrica material. De manera pues que habían acordado ofrecer la cantidad "de sólo 25000 pesos por vía de donativo para las nuevas urgencias de la corona". ${ }^{65}$

Como había venido sucediendo con los últimos oficios-respuesta y representaciones en relación con las innumerables solicitudes de donativos y la creación de nuevos impuestos, y para justificarse por ahora de contribuir con tan poca cantidad siendo tan gordo el problema, la antedicha respuesta del Cabildo Catedral michoacano estuvo acompañada de una larga lista de los últimos donativos, a la cual le agregaron los 8000 pesos que recientemente, en 1804, había ofrecido el senado episcopal al Ayuntamiento de la ciudad para la construcción de la fábrica de puros y cigarros que se establecería en la capital del obispado. Asimismo, nuevamente se hacía referencia a todos los últimos impuestos que habían mermado se-

${ }^{63}$ Ibid., fs. 52v.-53.

${ }^{64}$ Ibid., f. 33, "Valladolid. Año de 1805. Testimonio sobre donativo...”, en ACCM, leg. 144, año 1805 , f. 32

${ }^{65} \mathrm{Ibid}$., fs. $36-37 \mathrm{v}$. 
riamente los ingresos de los prebendados y la deuda de "una cantidad considerable" por los gastos que les había generado el pleito contra la diócesis de Guadalajara por los partidos de Colima, La Barca y Zapotlán el Grande. De paso, se aprovechó el momento para tocar un asunto de enorme seriedad y que preocupaba a los capitulares michoacanos, el rumor de la erección de nuevos obispados en Nueva España, que, decían, los hacía sentirse amenazados, seguramente porque esas nuevas diócesis se establecerían en territorios del obispado de Michoacán. ${ }^{66}$

Poco después, el 7 de octubre de 1807, el virrey Iturrigaray solicitó al Cabildo Catedral ayuda económica para el pago del numeroso personal que había provocado en la secretaría de cámara del virreinato un acuerdo de la Junta Superior de Real Hacienda, de fecha 7 de octubre de 1801, cuyos sueldos sobrepasaban los 11130 pesos anuales presupuestados para tal fin. En la respuesta que el senado episcopal michoacano dio a esta nueva petición vemos una vez más el crítico estado de las rentas de los prebendados: "después de una detenida meditación para facilitar su logro, no se presenta arbitrio alguno, ni por parte de nuestro cuerpo ni por la de los tribunales de este gobierno diocesano", decían de entrada los capitulares. Entender su posición era sencillo, si se tomaba en cuenta que "las rentas de esta santa Iglesia y de la mesa capitular están afectas a la contribución del real subsidio y otras iguales pensiones, y están gravadas también con los reportes consiguientes a la suma de donativos con que hemos contribuido gustosos en las urgencias del Real Erario en las comunes necesidades y en el beneficio de este público...", y en seguida se volvieron a pormenorizar cantidades y rubros en los que habían ayudado, en los que estaban gravadas sus rentas, y que también hemos referido anteriormente, 8000 pesos para la fábrica de puros y cigarros de la ciudad de Valladolid de Michoacán, la anualidad eclesiástica que había que pagar en el ingreso y ascenso, y el nuevo noveno. De manera pues que ni los prebendados ni los tribunales de la curia eclesiástica podían cooperar en ese momento, pues la burocracia de estos últimos también se había visto tan perjudicada en sus ingresos por la inflación del día y por los aranceles que pesaban sobre sus sueldos, que al difunto obispo fray Antonio de San Miguel y al Cabildo sede vacante les había sido preciso "auxiliarlos con extraordinarios socorros para estimular el desempeño de sus deberes". El colofón de aquella respuesta al virrey Iturrigaray fue, pues, la ya sospechada: "Dígnese vuestra excelencia disimular nuestra excusa. ${ }^{\prime 67}$

${ }^{66}$ Ibid., f. 38-38v.

${ }^{67}$ AHCM, Diocesano, Gobierno, Correspondencia, Autoridades Civiles, caja 32, años 18011814 , fs. s. n. 


\section{LA OCUPACIÓN FRANCESA Y LA CAUSA DE LA PATRIA}

La invasión de España por parte de los ejércitos napoleónicos vino a precipitar en la península una crisis que, como hemos visto, se había iniciado desde principios de la década de 1790 y que le había sido contagiada a Nueva España al imponérseles un excesivo número de exacciones fiscales a las corporaciones e individuos de este virreinato para las guerras contra la Francia revolucionaria e Inglaterra. Sin embargo, aquel evento bélico llevó a que los esfuerzos del Estado y la Iglesia se reuniesen y concentrasen en la defensa de la patria.

A partir de entonces, vemos en la documentación que el Cabildo Catedral de Valladolid de Michoacán concentra sus esfuerzos en apoyar de diversas maneras a las autoridades españolas en su lucha contra el invasor. Ya no vemos más aquellas encendidas representaciones para protestar contra impuestos y donativos. No podía ser de otra manera, pues la presencia francesa en tierras españolas significaba, entre muchas otras cosas, un peligro para el estatus de la Iglesia y, según se puede apreciar en una multitud de documentos de la época, generó preocupación y hasta angustia entre muchos que consideraban ateos, herejes y materialistas a los franceses.

Aquellos días fueron en Valladolid de Michoacán, pues, de juras a Fernando VII, misas con tedeum, oraciones pro tempore belli y procesiones, además de los infaltables sermones para encender los ánimos de los novohispanos en contra de los franceses y a favor de la defensa de España. Pero las cosas no quedaron en la pura celebración de misas y procesiones, sino que el senado episcopal michoacano también fue a hechos prácticos: acordó hacerle ciertas "ofertas" al virrey Iturrigaray "para la libertad de la religión y de la patria contra los insultos que la amenazan por el emperador de los franceses", y olvidando lo dicho algunos meses antes en el sentido de que no tenían ni quinto para apoyos económicos para pagarle a la burocracia de la secretaría de cámara del virreinato, acordaron, "a una voz, que se le hiciera presente al mismo señor excelentísimo estar prontos a concurrir por sí y todo el estado eclesiástico de esta vasta diócesis, que representan en la actual sede vacante, con sus rentas y bienes". ${ }^{68}$

En este escenario fue que, el 25 de agosto de 1808, se dio la jura de Fernando VII por parte del Ayuntamiento y del Cabildo Catedral de Valladolid de Michoacán, para lo cual se iluminaron y adornaron las torres y portada de la catedral, se hicieron repetidos repiques con el esquilón mayor, y el doctor Manuel de la Bárcena -el más fino orador existente en

${ }^{68}$ ACCM, Libros de Actas de Cabildo, libro 43, años 1807-1811, Sesión de Cabildo, 8 de agosto de 1808 , f. 95-95v. 
ese momento en el capítulo diocesano- fue el encargado de predicar el sermón ${ }^{69}$ "con erudición, elocuencia, celo por la religión y amor a nuestro deseadísimo soberano", en la misa solemne que con tal motivo se celebró en la catedral con tedeum laudamus. Además, ese jueves 25 de agosto pasaron al palacio episcopal los prebendados existentes en la ciudad; desde sus balcones arrojaron al público asistente 500 pesos en diversas monedas luego que presenciaron el segundo acto de la jura organizado por el alférez real, y por la noche hubo fuegos artificiales en la parte frontal de la catedral, además de repique de campanas en todas las iglesias de la ciudad. Los constantes repiques, iluminaciones y fuegos artificiales concentraron a la población completa en aquellas ceremonias los tres días que duraron. ${ }^{70}$

La invasión francesa a España y la entronización de Fernando VII generaron, pues, el efecto de que el Cabildo Catedral de Valladolid de Michoacán cerrara filas en aras de defender la patria y la religión, además de defender a Fernando VII. Ya hemos hablado de aquellas misas con tedeum laudamus y oraciones pro tempore belli. Pero ante la escasez de dinero, el 8 de agosto de 1808 el senado episcopal michoacano ofreció "los adornos, los vasos sagrados y todos los tesoros de los templos", además de ofrecer "sin la menor reserva nuestras rentas y nuestras propiedades", amén de comprometerse a "concurrir con nuestro concepto, nuestro influjo y con nuestras frecuentes exhortaciones para aumentar y sostener los generosos impulsos de la nobleza y pueblo". Aún más, y en un arranque de desenfrenada muestra de absoluta disposición, ofrecían, por último, sus personas:

nuestra sangre y nuestra vida -decían. Los jóvenes, sirviendo bajo las banderas de la lealtad, cambiaremos la vida por la seguridad de nuestro suspirado Fernando; y los ancianos mantendremos mientras tanto el culto divino, enviaremos al cielo ardientes plegarias, y en el último trance (que Dios evitará), moriremos gustosos entre el vestíbulo y el altar, víctimas al monarca y en holocausto de nuestra sagrada religión. ${ }^{71}$

Sin embargo, pocos meses más tarde, en octubre de 1808, decidieron que también había que aportar dinero a la causa, por lo que enviaron a la Real Hacienda la nada despreciable suma de 40000 pesos para cooperar en "salvar la sagrada persona de nuestro augusto, amado monarca, el señor don Fernando VII, libertar la religión y la patria de la crueldad y tira-

${ }^{69}$ Ese sermón es analizado por Herrejón en el contexto de otras piezas literarias del mismo tipo que se pronunciaron en otras ciudades de Nueva España durante aquel 1808. Herrejón, Sermón, 2003, pp. 267-270.

${ }^{70}$ ACCM, Libros de Actas de Cabildo, libro 43, años 1807-1811, "Certificación del bachiller Rafael Aragón sobre el acto de jura y proclamación de Fernando VII”, fs. 97v.-98v.

${ }^{71}$ AGN, Historia, vol. 46, t. 2, fs. 287-287v. 
nía del impío emperador de los franceses, Napoleón Bonaparte". Luego, ya entrado el año de 1809, se decidió hacer un "préstamo patriótico" -es decir, sin réditos- por 40000 pesos de todos los ramos de la gruesa decimal, para las urgencias de la corona, y en enero de 1810, no teniendo más dinero que ofrecer, el senado episcopal michoacano puso a la disposición del arzobispo virrey Lizana "todas las alhajas de esta santa Iglesia para el caso en que su excelencia conozca sean necesarias al socorro de las necesidades de la corona en la guerra tan justa y santa que mantiene contra el impío emperador de los franceses" ${ }^{72}$

Hacia 1810, los muchos impuestos y gravámenes de todo tipo que se habían cargado sobre las iglesias novohispanas a lo largo de los 20 años anteriores quedaron como un capítulo del pasado. La invasión napoleónica a España había conseguido reunir los intereses de las iglesias novohispanas con los del Estado, a la vez que había contribuido a que los propios hombres de la Iglesia vieran e hicieran ver a la población en general la necesidad de un levantamiento en cualquier momento.

Queda sin embargo la duda -y cabe ampliamente la posibilidad de ello- acerca de si, en lo particular, uno que otro prebendado generó y mantenía resentimientos hacia aquella generación de funcionarios españoles que habían echado a andar la política fiscal que había iniciado la decadencia económica del clero catedralicio.

Por último, más allá de sólo observar las cantidades de dinero que remitió una y otra vez la Iglesia michoacana a la Real Hacienda por diferentes motivos y para diferentes propósitos, conviene hacer un alto para pensar en los efectos que todo eso comenzó a tener en el nivel de vida de los miembros del clero catedralicio y, en consecuencia, en su concepción del gobierno del momento.

Por lo demás, no está de sobra insistir en el tema de la crisis económica que comenzó a vivir el clero catedralicio michoacano en el tránsito del siglo XVIII al XIX a consecuencia de la política fiscal borbónica y de los frecuentes donativos y préstamos patrióticos, y que comenzó a hacerse evidente no solamente en las percepciones económicas y en el nivel de vida del obispo y de los capitulares, sino en el antiguo esplendor y magnificencia que había tenido todo lo que rodeaba la liturgia en la catedral.

\footnotetext{
72 ACCM, Libros de Actas de Cabildo, libro 43, años 1807-1811, Sesiones de Cabildo, 1 y 15 de septiembre, del 27 de octubre de 1808, del 17 de agosto de 1809 y del 30 de enero de 1810 , fs. 99-99v., 101-101v., 106v.-107 y 149-149v. y 169v.
} 


\section{FUENTES CONSULTADAS}

\section{Archivos}

ACADVM Archivo Capitular de Administración Diocesana Valladolid-Morelia, Morelia, México.

ACCM Archivo del Cabildo Catedral de Morelia, Michoacán, México.

AGN Archivo General de la Nación, ciudad de México, México.

AHCM Archivo Histórico Casa de Morelos, Morelia, México.

\section{Bibliografía}

Brading, David A., Una Iglesia asediada: el obispado de Michoacán, 1749-1810, México, Fondo de Cultura Económica, 1994.

Cardoso Galué, Germán, Michoacán en el Siglo de las Luces, México, El Colegio de México, 1973.

Fonseca, Fabián de y Carlos Urrutia, Historia general de la Real Hacienda, México, Imprenta de Vicente García Torres, 1850, t. III.

Herrejón Peredo, Carlos, Del sermón al discurso cívico. México, 1760-1834, Zamora, El Colegio de Michoacán/El Colegio de México, 2003.

Klein, Herbert S., Las finanzas americanas del imperio español. 1680-1809, México, Instituto de Investigaciones Dr. José María Luis Mora, 1999.

Jaramillo Magaña, Juvenal, Hacia una Iglesia beligerante. La gestión episcopal de fray Antonio de San Miguel en Michoacán, (1784-1804). Los proyectos ilustrados y las defensas canónicas, Zamora, El Colegio de Michoacán, 1996.

Lemoine, Ernesto, Morelos y la revolución de 1810, Morelia, Gobierno del Estado de Michoacán, 1979.

MARICHAL, CARlos, La bancarrota del virreinato. Nueva España y las finanzas del imperio español, 1780-1810, México, El Colegio de México/Fideicomiso Historia de las Américas/Fondo de Cultura Económica, 1999.

Martínez López-Cano, Pilar y Valle Pavón, Guillermina del (coords.), El crédito en Nueva España, México, Instituto de Investigaciones Dr. José María Luis Mora/El Colegio de Michoacán/El Colegio de México/Universidad Nacional Autónoma de México, 1998.

Sugawara H., MASAE (prólogo, bibliografía y selección de documentos), La deuda pública de España y la economía novohispana, 1804-1809, México, Instituto Nacional de Antropología e Historia, 1976 (Colección Científica, núm. 28).

“Testimonio de la erección canónica de la Iglesia Catedral de Michoacán, dado a conocer por el obispo Vasco de Quiroga, en el año de 1554" en JuAn José Moreno, Fragmentos de la vida y virtudes de don Vasco de Quiroga, estudio introductorio por Ricardo León Alanís, Morelia, Centro de Estudios sobre la Cultura Nicolaita/ 
Universidad Michoacana de San Nicolás de Hidalgo, 1998 (edición facsimilar de la impresa en 1766).

Torales Pacheco, Ma. Cristina, "La imperial orden de Guadalupe: condecorar a los líderes de la Independencia" en AA. VV., Historia desconocida. Una aportación a la historia de la Iglesia en la independencia de México. Libro anual 2009 de la Sociedad Mexicana de Historia Eclesiástica, México, Minos III Milenio Editores, 2009.

Valle Pavón, Guillermina DEl, "Las corporaciones religiosas en los empréstitos negociados por el Consulado de México a finales del siglo XVIII" en MARÍA DEL Pilar Martínez LóPeZ-CANO (coord.), Iglesia, Estado y economía, siglos XVI al XIX, México, Instituto de Investigaciones Dr. José María Luis Mora/Universidad Nacional Autónoma de México, 1995.

"El apoyo financiero del Consulado de Comerciantes a las guerras españolas del siglo XVIII" en María del Pilar Martínez LóPez-Cano y GuillermiNA del Valle Pavón (coords.), El crédito en Nueva España, México, Instituto de Investigaciones Dr. José María Luis Mora/El Colegio de Michoacán/El Colegio de México/Universidad Nacional Autónoma de México, 1998. 